\title{
ESTUDO DA Fasciola hepatica LINAEUS,1758 (Trematoda fasciolidae) NOS MUNICÍPIOS DE BOCAIÚVA DO SUL E TUNAS DO PARANÁ, NO ESTADO DO PARANÁ, BRASIL
}

\author{
Fasciola hepatica LINAEUS, 1758 (Trematoda fasciolidae) \\ IN THE BOCAIÚVA DO SUL AND TUNAS DO PARANÁ COUNTIES, \\ IN THE STATE OF PARANÁ, BRAZIL
}

\author{
Valter da Silva QUEIROZ \\ Orientador: Professor Ennio LUZ \\ Departamento de Patologia Básica - UFPR
}

\begin{abstract}
RESUMO
Em estudos realizados sobre Fasciola hepatica em 42 propriedades distribuídas nos municípios de Bocaiúva do Sul e Tunas do Paraná, no Estado do Paraná, Brasil, durante o período de novembro de 1998 a fevereiro de 1999 verificou-se o seguinte: Mediante levantamento da fauna de Molusca Pulmonata efetuado nas referidas propriedades, da população de Molusca - Pulmonata identificada, 22 (52\%) das propriedades apresentaram Lymnaea columella e $4(9 \%)$ apresentaram Physa marmorata. Em busca realizada mediante dissecção dos moluscos encontrados, em nenhum deles foram observadas larvas de Fasciola hepatica. Através de exame parasitológico de fezes para a pesquisa de ovos realizado com amostragens dos rebanhos bovinos e ovinos das propriedades pesquisadas, identificou-se a infecção por $F$. hepatica em 4 (10\%) das propriedades. Do total das propriedades, 2 (17\%) dos rebanhos ovinos e $3(8 \%)$ dos rebanhos bovinos estavam infectados. Em experimento laboratorial visando testar a susceptibilidade dos moluscos $L$. columella e $P$. marmorata à infecção por miracídios

oriundos do local, somente a $L$. columella desenvolveu a infecção. Através de estudo do perfil epidemilógico da fasciolose bovina em propriedade situada na área urbana do município de Bocaiúva do Sul, encontrou-se $L$. columella e $P$. marmorata durante todo o período compreendido entre janeiro de 1995 e novembro de 1996, excetuado o mês de abril de 1996 quando encontrou-se apenas P. marmorata. O maior pico populacional das duas espécies foi encontrado em maio de 1996. Quando à presença de infecção natural por larvas de $F$. hepatica, foi verificada somente em $L$. columella, em março e abril de 1995. No período pesquisado, em 3 levantamentos realizados examinando os animais do rebanho individualmente através de pesquisa de ovos do parasita por exame parasitológico de fezes, foram obtidos os seguintes índices de infecção por F. hepatica: Mar./95: 9,09\%, Ago./96: $40 \%$ e Nov. $/ 96 \%$. Na área em estudo, observou-se que existe a Fasciola hepatica em forma autóctene e o hospedeiro intermediário é a Lymnaea columella, a qual está amplamente distribuída na área, constituindo risco como zoonose.
\end{abstract}

\begin{abstract}
In studies done about Fasciola hepatica in 42 properties in the urban communities of Bocaiúva do Sul and Tunas do Paraná, in state of Paraná, Brazil, during the period of November 1998 to February 1999, we observed the following: Through the Molusca - Pulmonata fauna survey done in those mentioned properties, of the Molusca - Pulmonata population identified, 22 (52\%) of the properties showed Lymnaea columella 4 (9\%) presented Physa marmorata. In an investigation fulfilled through the dissection of the found mollusks, no larva of Fasciola hepatica were found in any of them. Trough lees parasitological investigation for egg survey accomplished with ovine and cattle herds samples of searched properties, the infection by F. hepatica was found in $4(10 \%)$ of the properties. From the total of the of the properties, $2(17,7 \%)$ of the ovine flocks and $3(8 \%)$ of the cattle herds were infected. In laboratorial investigations aiming to test the Lymnaea columella and Pulmonata marmorata mollusks susceptibility to infections by miracidium arising from

the local properties, only the Lymnaea columella has developed in infection. Through the study of the epidemiological aspect of the fasciola in cattle located in the properties in the urban area of the municipality of Bocaiúva do Sul, L. columella and P. marmorata were found during the whole period between January, 1995 and November, 1996, except in April, 1996 when only P. marmorata was verified. The highest peak of population of the two species was found in May, 1996. Concerning to the presence of natural infection by $F$. hepatica larva, only $L$. columella was verified in March and April, 1995. In the searched period, in thee surveys fulfilled, examining the animals individually through the parasite egg investigation using lees parasitological inquiry, we have got the following infection tables by F. hepatica. March/95: 9,09\%, August $/ 96: 40 \%$, and November/96: $40 \%$ In the studied area we observed that there is a Fasciola hepatica with the autochthonal shape and the intermediate landlord is the Lymnaea colunela which is widely spread in the area, representing a risk as zoonosis.
\end{abstract}

